\title{
Pelatihan Daring Penulisan Artikel Ilmiah Bagi Guru Sekolah Menengah Kejuruan Negeri 1 Sidoarjo
}

\author{
Fitria Nur Hasanah ${ }^{1}$, Fika Megawati², Noly Shofiyah ${ }^{3}$, Miftahul Jannah ${ }^{4}$, Rindiani $^{5}$ \\ Universitas Muhammadiyah Sidoarjo $1,2,3,4,5$ \\ fitrianh@umsida.ac.id, fikamegawati@umsida.ac.id, nolyshofiyah@umsida.ac.id, jannahmiftahul858@gmail.com, \\ rindiani218@gmail.com
}

\begin{abstract}
As a professional teacher must have various abilities, one of the ability to write scientific papers in the form of scientific articles. By writing scientific papers, in addition to getting a promotion, position and class, will be used as a benchmark of success and to demonstrate professionalism. Departing from the problems at the partner school, the purpose of this training activity is to improve teachers' understanding and ability to write scientific articles that are in accordance with the journal template. The target of this activity is teachers at SMK N 1 Sidoarjo. The methods used in this training are lecture, question and answer, mentoring to write scientific articles, and citing references. Based on the results of the pre-test and post-test conducted during the training showed that there was an increase in knowledge about writing scientific articles. Increasing the percentage of knowledge about the article component by 46\%, increasing the ethical knowledge of writing articles by 58\%, and increasing knowledge about uploading articles in national journals by $54 \%$.
\end{abstract}

Keywords: Online training; Scientific articles; Scientific papers.

\begin{abstract}
Abstrak
Sebagai guru profesional harus memiliki berbagai kemampuan, salah satu kemampuan menulis karya tulis ilmiah berupa artikel ilmiah. Dengan menulis karya tulis ilmiah, selain mendapat kenaikan pangkat, jabatan dan golongan, akan dijadikan tolak ukur keberhasilannya serta untuk menunjukkan keprofesionalannya. Berangkat dari permasalahan pada sekolah mitra tersebut, maka tujuan kegiatan pelatihan ini adalah untuk meningkatkan pemahaman dan kemampuan guru dalam menulis artikel ilmiah yang sesuai dengan template jurnal. Sasaran kegiatan ini adalah guru di SMK N 1 Sidoarjo. Metode yang digunakan dalam pelatihan ini adalah presentasi daring, tanya jawab, pendampingan menulis artikel ilmiah, dan pengutipan referensi. Berdasarkan hasil pretest dan posttest yang telah dilakukan saat pelatihan menunjukkan bahwa terdapat peningkatan pengetahuan tentang penulisan artikel ilmiah. Peningkatan persentase pengetahuan tentang komponen artikel sebesar $46 \%$, peningkatan pengetahuan etika penulisan artikel sebesar 58\%, dan peningkatan pengetahuan tentang upload artikel pada jurnal nasional sebesar $54 \%$.
\end{abstract}

Kata Kunci: Pelatihan; Artikel ilmiah; Karya tulis ilmiah. 


\section{A. PENDAHULUAN}

Pendidikan merupakan hal yang penting dalam pembangunan bangsa dan negara. Guru merupakan ujung tombak dalam dunia pendidikan. Untuk itu guru harus terus-menerus meningkatkan kompetensi professional dikarenakan guru memiliki peran yang strategis. Dalam upaya mewujudkan guru profesional, pemerintah menetapkan Peraturan Pemerintah No 19 Tahun 2005 tentang Standar Pendidikan Nasional, yang menyatakan bahwa guru diharapkan memiliki 4 (empat) kompetensi, yaitu pedagogik, kepribadian, profesional, dan sosial (Mulyasa, 2009).

Kompetensi profesional seorang guru berhubungan dengan penyelesaian tugas keguruan, salah satu tuntutan professional tersebut adalah kemampuan guru dalam melaksanakan penelitian dan berfikir ilmiah untuk meningkatkan kinerja mereka. Selain itu, guru sebagai masyarakat akademik berkepentingan untuk mengembangan ilmu pengetahuan dan teknologi serta pemecahan permasalahan yang dihadapi masyarakat (Santoso, 2007). Salah satu upaya yang dilakukan pemerintah agar profesionalisme guru meningkat adalah dengan adanya program sertifikasi guru (Sudjana \& Laksana, 2012). Sertifikasi guru adalah proses pemberian sertifikat pendidik kepada guru dan dosen, dimana sertifikat pendidik merupakan bukti formal pengakuan yang diberikan kepada guru dan dosen sebagai jabatan profesional.

Sesuai dengan Peraturan Menteri Negara Pendayagunaan Aparatur Negara dan Reformasi Birokrasi Nomor 16 Tahun 2009 tentang Jabatan Fungsional Guru dan Angka Kreditnya Bab V Pasal 11 Poin C tentang publikasi ilmiah, pengembangan keprofesionalan berkelanjutan meliputi (1) melaksanakan pengembangan diri; (2) melaksanakan publikasi ilmiah; dan (3) melaksanakan karya inovativ. Salah satu upaya yang perlu dilakukan dalam rangka meningkatkan profesionalisme guru adalah menulis karya ilmiah (Keputusan bersama Menteri Pendidikan dan kebudayaan dan Kepala BAKN Nomor 0433/P/1993, nomor 25 tahun 1993 tentang Petunjuk Pelaksanaan Jabatan Fungsional Guru dan Angka Kreditnya, 2009).

Karya tulis ilmiah merupakan tulisan yang berisi gagasan kreatif yang disusun secara komprehensif berdasarkan data yang akurat, dianalisis secara runtut, tajam dan diakhiri dengan kesimpulan yang relevan. Hal ini sejalan dengan Undang-Undang Republik Indonesia No. 14 tahun 2005 tentang Guru dan Dosen, pasal 20 poin b, yang menyatakan bahwa dalam melaksanakan tugas keprofesionalannya, guru berkewajiban untuk meningkatkan dan mengembangkan kualifikasi akademik dan kompetensi secara berkelanjutan sejalan dengan perkembangan ilmu pengetahuan, teknologi, dan seni (Undangundang Nomor 14 Tahun 2005, 2005) . Kemampuan menulis karya ilmiah sangat penting artinya bagi guru. Tulisan ilmiah yang berisi hasil penelitian, hasil pengkajian, hasil pemikiran, dan karya guru lainnya, sangat potensial sebagai wahana komunikasi dan diseminasi karya kepada guru atau pihak-pihak yang terkait dengan dunia pendidikan (Arta, 2019).

Guru yang tidak mampu menulis akan mengalami kendala berkomunikasi karena dalam melaksanakan tugas seharihari seorang guru dituntut mampu menulis seperti menulis surat dinas, menulis laporan kegiatan, dan menulis karya ilmiah untuk kenaikan pangkat (Sudirman et al., 2017).

Keterampilan menulis karya ilmiah bagi guru sangat penting. Kemampuan guru dalam menulis karya ilmiah dan menerbitkannya di jurnal ilmiah adalah 
salah satu upaya untuk mendapatkan angka kredit yang dapat dipergunakan dalam persyaratan peningkatan karir atau kenaikan pangkat. Sesuai dengan PERMENPAN No. 16 Tahun 2009 jumlah angka kredit guru yang membuat karya tulis berupa laporan hasil penelitian pada bidang pendidikan di sekolahnya, diterbitkan/ dipublikasikan dalam majalah/jurnal ilmiah tingkat nasional yang terakreditasi sebanyak 3 poin (Keputusan Menteri Negara Pendayagunaan Aparatur Negara nomor 84/1993 tentang Jabatan Fungsional Guru dan Angka Kreditnya., 2009). Membuat karya tulis berupa laporan Ide atau inspirasi guru dalam menulis dapat diperoleh dengan mudah melalui permasalahan yang terjadi di sekitarnya, khususnya dalam proses pembelajaran di kelas. Karya tulis tersebut dapat berupa hasil penelitian, pengkajian, survey, dan evaluasi.

Namun, permasalahan yang dihadapi guru adalah belum dapat menuangkannya ke dalam sebuah artikel ilmiah yang layak untuk dipublikasikan dan dikonsumsi oleh masyarakat sehingga motivasi untuk menulis karya ilmiah masih minim dikarenakan pengetahuan aspek-aspek teknik menulis karya ilmiah. Bagi sebagian guru, karya ilmiah merupakan hal yang dianggap "pekerjaan yang sulit". Akibatnya karya ilmiah menjadi hambatan dalam berbagai hal. Padahal kemampuan menulis karya ilmiah menjadi keharusan bagi seorang guru profesional. Baik dalam peningkatan karier maupun peningkatan pengetahuan dan intelektualitas yang harus dimiliki oleh seorang guru dalam proses pembelajarannya.

Pelatihan penulisan artikel ilmiah ini dinilai penting dilakukan mengingat masih banyak guru yang mengalami kesulitan dalam membuat karya ilmiah dalam hal ini adalah artikel ilmiah. Sementara itu guru dituntut untuk menjadi pendidik professional seperti yang tercantum pada UU Guru dan Dosen. Kegiatan pengembangan profesi itu meliputi (1) membuat karya tulis/karya ilmiah di bidang pendidikan, menemukan teknologi dibidang pendidikan, (3) membuat alat pembelajaran/alat peraga atau alat bimbingan, (4) menciptakan karya tulis ilmiah, dan mengikuti kegiatan pengembangan kurikulum (Soedarsono, 2001).

Berdasarkan hasil wawancara dengan Wakil Kepala SMK N 1 Sidoarjo bidang Humas diketahui bahwa guru-guru masih kesulitan dalam membuat karya tulis ilmiah baik berupa laporan hasil penelitian maupun artikel ilmiah yang dipublikasi di jurnal ilmiah. Menurut (Suyanto, 2009) terdapat sekitar 410.000 guru yang berpangkat IV/a masih mengalami kesulitan untuk kenaikan pangkat berikutnya karena adanya persyaratan menulis karya ilmiah. Hal ini didukung kesibukan guru dalam menyelesaikan administrasi di sekolah dan tidak adanya waktu luang untuk menulis artikel ilmiah.

Mitra dalam kegiatan ini adalah SMK N 1 Sidoarjo yang telah memperoleh akreditasi A yang berada di tengah kota Sidoarjo tepatnya di Jalan Mangonsidi Nomor 71 Sidoklumpuk, Sidokumpul, Kecamatan Sidoarjo Kabupaten Sidoarjo. Guru yang berstatus PNS sejumlah 75 orang dan hampir semua tersertifikasi. Hanya saja menurut Wakil Kepala Sekolah Bidang Humas menyampaikan untuk kenaikan jabatan fungsional, beberapa guru cenderung lama dikarenakan keengganan untuk menulis baik buku maupun karya tulis ilmiah yang lainnya. Sehingga dalam diskusi awal dengan pihak mitra maka disepakati dilakukan kegiatan pelatihan. Untuk membantu guru dalam meningkatkan keterampilan penulisan karya ilmiah dan 
publikasi artikel di jurnal nasional terakreditasi, maka akan dilakukan pelatihan dan pendampingan pada Mitra tersebut yang bertajuk "Pelatihan Penulisan Artikel Jurnal Ilmiah Bagi Guru di SMK N 1 Sidoarjo".

\section{B. PELAKSANAAN DAN METODE}

Permasalahan yang muncul pada guru terkait permasalahan rendahnya publikasi dalam jurnal maupun prosiding nasional, kemudian dilakukan diskusi pengusul bersama mitra untuk merumuskan akar masalah prioritas yang disepakati, serta menentukan solusi yang tepat. Metode yang digunakan dalam kegiatan pelatihan ini antara lain pelatihan dengan daring (in) dan pendampingan penyusunan artikel melalui grup whatsapp (on). Kegiatan awal yang direncanakan dan disepakati adalah pelatihan dan pendampingan secara tatap muka di kelas. Tetapi dikarenakan pelatihan tatap muka belum bisa terlaksana akibat covid 19 maka disepakati bersama antara pengabdi dengan pihak mitra bahwa pelatihan dilakukan secara daring.

Kegiatan pelatihan ini dilaksanakan dengan 3 tahap, tahap yang pertama yaitu persiapan. Tahap persiapan meliputi diskusi dengan mitra dan tim terkait pelaksanaan pelatihan, penyusunan instrument pelatihan yang meliputi angket keterlaksanaan pelatihan, rundown kegiatan, dan menyusun materi yang akan disampaikan pada pelatihan. Selain itu tahap persiapan yang dilakukan oleh pengabdi adalah membuat modul tata cara penggunaan metode daring melalui google meet dan pembuatan grup whatsapp untuk koordinasi. Koordinasi awal yang dilakukan adalah memberikan bimbingan terkait penggunaan metode daring dengan google meet.

Tahap yang kedua yaitu tahap pelaksanaan, pada tahap ini pengabdi melaksanakan pelatihan dengan metode daring. Sebelum itu pengabdi memastikan peserta dapat mengakses link yang telah diberikan di grup whatsapp. Karya tulis ilmiah yang dibahas dalam pelatihan ini adalah karya tulis hasil peneitian dan telaah pustaka atau gagasan ilmiah. Sesuai dengan pernyataan (Djuroto \& Supriyadi, 2007) karya tulis ilmiah dapat dipilah dalam dua kelompok yaitu: (1) karya tulis ilmiah yang merupakan laporan hasil pengkajian/ penelitian; dan (2) karya tulis ilmiah yang berupa tinjauan, ulasan, atau gagasan ilmiah.

Tahap yang terakhir yaitu evaluasi, pada tahap evaluasi ini pengabdi memberikan refleksi dan berdiskusi terkait pelaksanaan pelatihan, selanjutnya pengabdi memberikan angket respon untuk mengetahui peningkatan pengetahuan penulisan artikel ilmiah. Partisipan dari kegiatan pelatihan ini adalah 20 Guru SMK N 1 SIdoarjo.

\section{HASIL DAN PEMBAHASAN}

Pelatihan penulisan artikel ilmiah dilaksanakan dengan dua tahapan yaitu in dan on. Tahap in pada pelatihan yang dimaksud adalah pelaksanaan pelatihan dengan tatap muka melalui metode daring. Pelaksanaan kegiatan pelatihan penulisan artikel ilmiah untuk Guru SMK N 1 Sidoarjo terlaksana pada tanggal 20 April 2020 dan diikuti oleh 20 peserta. Materi yang telah disampaikan pada pelatihan daring ini adalah (1) sharing pengalaman menulis artikel dan submit artikel pada jurnal nasional, (2) penulisan artikel ilmiah sesuai dengan template jurnal nasional, (3) etika penulisan karya ilmiah, (4) penulisan referensi dengan software mendeley, (5) upload artikel ilmiah pada sistem jurnal online (Open Journal System). 


\section{Tahap Persiapan}

Kegiatan pelatihan ini diawali dengan pembentukan tim abdimas dan pembagian tugas, koordinasi dengan pihak mitra yaitu SMK N 1 Sidoarjo terkait jadwal dan tempat pelaksanaan, penyusunan rundown kegiatan, penyusunan materi, dan pembuatan soal evaluasi. Dikarenakan pandemic covid 19 maka kegiatan yang semula akan dilaksanakan dengan tatap muka pada tanggal 21 Maret 2020 di aula perpustakaan SMK N 1 Sidoarjo, diubah dengan metode pelatihan daring yang dilaksanakan pada tanggal 21 April 2020 dengan menggunakan aplikasi google meet. Sebelum pelaksanaan pelatihan daring, pengabdi berkoordinasi dengan peserta pelatihan melalui grup whatsapp. Koordinasi yang dilakukan meliputi bimbingan penggunaan platform daring yaitu google meet. Pengabdi membuat modul yang berisi tata cara penggunaan google meet.

\section{Tahap Pelaksanaan}

Kegiatan awal pada saat pelaksanaan adalah memastikan peserta memperoleh signal yang bagus dan dapat mengakses google meet dan dapat bergabung adalam pelatihan daring. Link google meet pada pelatihan daring adalah : https://meet.google.com/dxm-eeig-xpe.

Tahap selanjutnya adalah pemberian pretest untuk mengetahui kemampuan awal terkait penulisan karya tulis ilmiah berupa artikel ilmiah. Pemaparan materi dilaksanakan sesuai dengan rundown yang telah dibuat untuk pelatihan daring. Kegiatan pelatihan dari dibagi menjadi empat (4) sesi. Sesi pertama disampaikan oleh Fika Megawati terkait sharing pengalaman menulis artikel dan submit artikel pada jurnal nasional dan Penulisan artikel ilmiah sesuai dengan template jurnal nasional. Pada sesi ini dijelaskan komponenkomponen yang terdapat pada artikel ilmiah.
Sesi kedua disampaikan oleh Fitria Nur Hasanah, terkait Etika penulisan karya ilmiah dan penulisan referensi dengan software mendeley. Poin penting yang disampaikan pada sesi ini adalah pentingnya originalitas artikel yang dibuat sehingga meminimalisir terjadinya plagiarism.

Sesi ketiga oleh Noly Shofiyah terkait tata cara upload artikel ilmiah pada sistem jurnal online (Open Journal System), dimulai dari cara pencarian jurnal sasaran pada sinta (sinta.ristekbrin.go.id/), pendaftaran dan submit artikel melalui system jurnal online. Dan sesi keempat yaitu diskusi tanya jawab. Pada saat diskusi Tanya jawab beberapa peserta menanyakan terkait template dan tips mencari jurnal sasaran untuk penulis pemula.

Peserta sangat antusias terutama pada saat materi terkait template jurnal dan upload jurnal pada system online. Beberapa pertanyaan disampaikan terkait sistematika artikel, upload jurnal, dan pencarian jurnal terakreditasi pada sinta. Dokumentasi kegiatan selama pelatihan berlangsung dapat ditunjukkan pada Gambar 1.

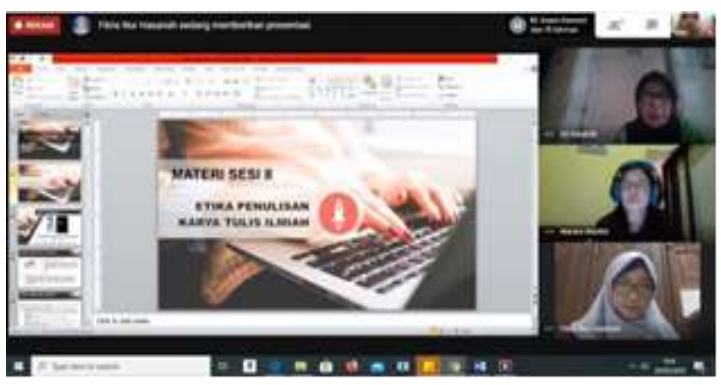

Gambar 1. Dokumentasi pelaksanaan pelatihan daring

\section{Tahap Evaluasi}

Tahap akhir pada pelatihan adalah evaluasi dengan memberikan angket posttest yang diakses melalui google form dengan link https://forms.gle/ypJYuZmuqRmUkpdS6. Hasil pelaksanaan pelatihan daring penulisan artikel ilmiah menunjukkan 
peningkatan prosentase pengetahuan peserta pelatihan terkait penulisan artikel ilmiah berdasarkan hasil pretest dan posttest. Hasil peningkatan dapat ditunjukkan melalui pie chart. Pada Gambar 2. Menunjukkan pengetahuan peserta pelatihan terkait komponen yang terdapat pada artikel jurnal ilmiah.
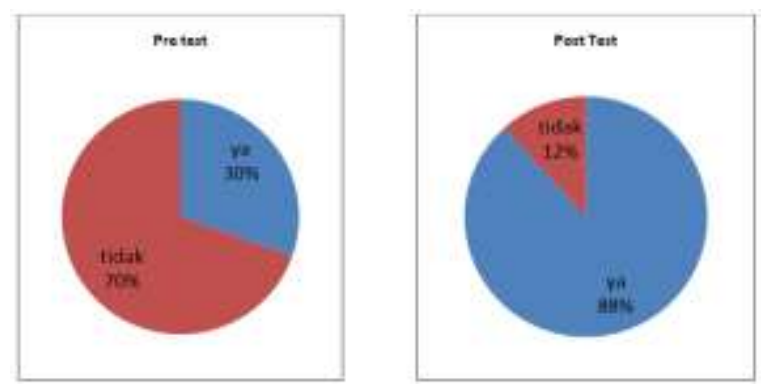

Gambar 2. Pie Chart Pengetahuan Komponen Artikel

Berdasarkan Gambar 2 diketahui pengetahuan terkait komponen artikel sebelum dan setelah pelatihan meningkat sebesar $46 \%$. Pada Gambar 3. menunjukkan pengetahuan peserta pelatihan terkait etika penulisan artikel jurnal ilmiah.
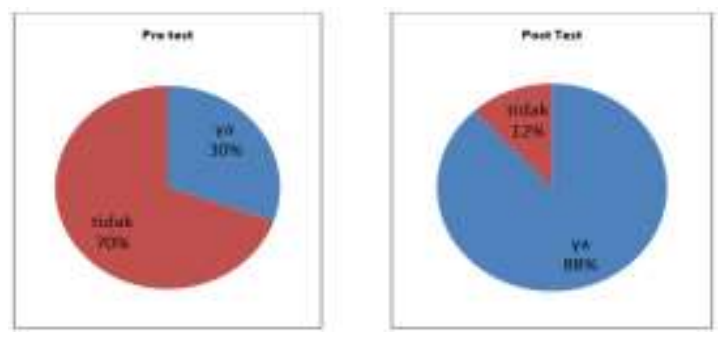

Gambar 3. Pie Chart Pengetahuan Etika Penulisan Artikel

Berdasarkan Gambar 3 diketahui pengetahuan terkait etika penulisan artikel ilmiah sebelum dan setelah pelatihan meningkat sebesar $58 \%$. Pada Gambar 4. menunjukkan pengetahuan peserta pelatihan terkait sistem untuk mengupload jurnal nasional.
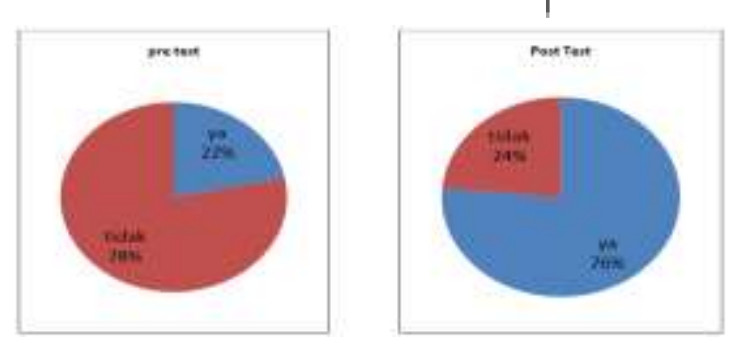

Gambar 4. Pie Chart Pengetahuan Upload Jurnal Online

Berdasarkan Gambar 4 diketahui pengetahuan terkait etika penulisan artikel ilmiah sebelum dan setelah pelatihan meningkat sebesar $58 \%$.

Prosentase tersebut diperoleh dari pemberian angket pre test dan post test yang dilaksanakan melalui google form yang kemudia diisi oleh peserta melalui link https://forms.gle/ypJYuZmuqRmUkpdS6.

\section{PENUTUP}

\section{Simpulan}

Melalui pelatihan daring penulisan artikel ilmiah ini dapat disimpulkan guru SMK N 1 Sidoarjo sangat antusias dalam mengikuti pelatihan artikel jurnal ilmiah, melalui pelatihan penulisan artikel ilmiah, pengetahuan guru-guru SMK N 1 Sidoarjo tentang penulisan artikel ilmiah meningkat. Hal ini ditunjukkan dengan peningkatan prosentase pengetahuan tentang komponen artikel sebesar 46\%, peningkatan pengetahuan etika penulisan artikel sebesar $58 \%$, dan peningkatan pengetahuan tentang upload artikel pada jurnal nasional sebesar 54\%, dan guru-guru mampu membuat artikel jurnal ilmiah sesuai dengan template jurnal sesuai dengan bidang keahlian masing-masing.

\section{Saran}

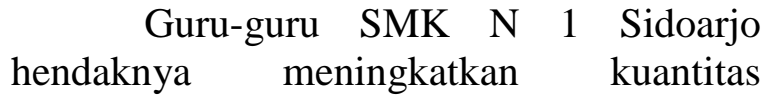


penulisan karya tulis ilmiah berupa artikel jurnal dan mengunggah artikel ilmiah ke jurnal terakreditasi sinta.

\section{Ucapan Terima Kasih}

Ucapan terimakasih disampaikan kepada Universitas Muhammadiyah Sidoarjo yang telah memberikan kesempatan berupa bantuan hibah abdimas institusi serta kepada Bapak Ibu Guru SMK N 1 Sidoarjo atas partisipasinya dalam pelatihan penulisan artikel ilmiah ini.

\section{E. DAFTAR PUSTAKA}

Arta, K. S. (2019). Pelatihan Penulisan Artikel Untuk Publikasi Di Jurnal Ilmiah Untuk Meningkatkan Profesionalisme Bagi Guru-Guru Di Kecamatan Kubutambahan Kabupaten Buleleng. Acarya Pustaka, 5(2), 17. https://doi.org/10.23887/ap.v5i2.17412

Djuroto, T., \& Supriyadi, B. (2007). Menulis Artikel dan Karya Ilmiah. Remaja Rosda Karya.

Keputusan bersama Menteri Pendidikan dan kebudayaan dan Kepala BAKN Nomor 0433/P/1993, nomor 25 tahun 1993 tentang Petunjuk Pelaksanaan Jabatan Fungsional Guru dan Angka Kreditnya, (2009).

Keputusan Menteri Negara Pendayagunaan Aparatur Negara nomor 84/1993 tentang Jabatan Fungsional Guru dan Angka Kreditnya., (2009).

Mulyasa, E. (2009). Standar Kompetensi dan Sertifikasi Guru. Remaja Rosdakarya.

Santoso, S. (2007). Kiat dan Strategi Menulis Karya Ilmiah. In Makalah disampaikan pada pelatihan penulisan
Karya Tulis Ilmiah Bagi Dosen-dosen PPSD FIP UNY.

Soedarsono. (2001). Aplikasi Penelitian Tindakan Kelas. Direktorat Jenderal Pendidikan Tinggi Departemen Pendidikan Nasional.

Sudirman, A., Dupri, M. D., \& Pranoto, H. (2017). Ilmiah Bagi Guru Di Sekolah Muhammadiyah. 1(1), 14-24.

Sudjana, N., \& Laksana, U. (2012). Menyusun Karya Tulis Ilmiah untuk Memperoleh Angka Kredit. Sinar Baru Algesindo.

Suyanto. (2009). Teknik Penulisan Artikel Ilmiah. In seminar KTI untuk guru di DIY.

Undang-undang Nomor 14 Tahun 2005, (2005). 